\title{
Serum Epidermal Growth Factor in Cancer Breast
}

\author{
El-Attar $\mathrm{HA}^{*}$, Moghazy $\mathrm{TF}^{*}$, Fadaly $\mathrm{GA}^{\star *}$, Abou Diba Ml ${ }^{\star \star *}$
}

\begin{abstract}
Several prognostic factors are evaluated in the breast carcinoma and there is a need for new markers for better discrimination of the biologic differences in the primary tumor. Epidermal growth factor (EGF) is presumed to play an important role in the local regulation of breast cell proliferation so, the aim of the current study, was to evaluate the serum level of EGF in breast cancer female patients in comparison with other prognostic parameters. It was carried out on fifty-seven females divided into two groups. A control group of twenty healthy women of comparable age and socioeconomic status with a group of thirty-seven breast cancer patients. All females were chosen non-pregnant, not on contraceptive therapy, not previously exposed to radiation, and have no previous history of cancer. To all patients, thorough clinical examination, plain X-ray for the chest and ultrasonography of the abdomen and pelvis were done. Preoperative fine needle aspiration cytology was also done for their breast lumps. In addition, blood samples were collected and analyzed for hemoglobin, fasting serum glucose, urea, and creatinine levels, aspartate and alanine aminotransferase activities, and also the epidermal growth factor level. The breast cancer tissues, removed by surgery, were subjected to histopathologic examination. The median of serum EGF in breast cancer patients group was relatively lower than that in control group but it did not reach the level of significance. No significant differences between the serum EGF levels were found in relation to the change in tumor size, type, grade, and stage. However, there was positive correlations between EGF level and tumor size $(r=0.341, p=0.039)$ and AJCC stages $(r=0.354, p=0.032)$. Also, in patients without lymph node metastasis, there were positive correlations between serum EGF level and both tumor size $(r=0.596, p=0.024)$ and AJCC stages $(r=0.596, p=0.024)$. In patients having lymph node metastasis, there was significant negative correlation between serum EGF level and the number of lymph node metastasis $(r=-0.859, p<0.001)$. There was significant increase in EGF level in patients having lymph node metastasis ( $\leq 3 \mathrm{LN}$ ) when compared to patients having no $L N$ metastasis $(p=0.004)$ and its level in patients having ( $>3 L N)$ metastasis was significantly decreased than that in both patients having no LN metastasis $(p=0.019)$ and patients having $\leq 3$ LN metastasis $(p<0.001)$. In addition, EGF level was significantly increased in patients with estrogen receptor $(E R)$ negative than in patients with ER positive $(p=0.049)$. Also, there was a negative correlation between EGF level and ER positivity $(r=-0.454, p=0.005)$. Similar correlation was also found in patients having $L N$ metastasis $(r=-0.680, p<0.001)$. But there was no significant relationship between serum EGF level and the state of progesterone receptor. In conclusion, determination of serum EGF in combination with certain histological parameters could be useful in determining tumor prognosis and in deciding the selection of treatment modality, however, more better results could be obtained on adding the determination of Epidermal growth factor receptor (EGRF) level in resected tumors.
\end{abstract}

Key words: Breast cancer; Epidermal growth factor (EGF); Epidermal growth factor receptor (EGFR).

\footnotetext{
${ }^{*}$ Chemical Pathology Department, Medical Research Institute,

** Pathology Department, Medical Research Institute,

${ }^{* * *}$ Experimental and Clinical Surgery Department, Medical Research Institute, Alexandria University
} 


\section{INTRODUCTION}

Growth factors like epidermal growth factor (EGF), insulin-like growth factors (IGFs), and transforming growth factors (TFGs) are among the critical regulators of cell proliferation for normal breast tissue ${ }^{(1,2)}$

The control of proliferation of human breast carcinoma is known to involve complex interactions between hormones and growth factors, e.g, prolactin, insulin, IGF-1, EGF, and basic fibroblast growth factor-(3,4) It has been found that IGF-1 and EGF appeared to stimulate human breast stromal cell growth in a synergistic manner.(5) Of these, EGF is the most important.(6)

The EGF is a single polypeptide chain having asparagine at $\mathrm{NH} 2$-terminus, arginine at $\mathrm{COOH}$-terminus, and a total of 53 amino acid residues, ( $6 \mathrm{KDa})$ with three internal disulfide linkages.(7) It is synthesized as a precursor of 1217 amino acids which include at least seven repeat amino acid sequences homologous to the original 53 amino acid EGF mitogen. There is no indication of the biological activity for EGF precursors.(8) EGF in human body stimulates proliferation of cells derived from ectoderm and mesoderm, it also inhibits gastric secretion.(9)

The EGF can be detected in many tissues and nearly all body fluids but high levels of EGF exist in saliva, urine, gastric juice, milk, breast cyst fluid, and also in amniotic fluid.(10-12)

As a mitogen, EGF binds, with high affinity, to specific cell surface receptors (EGFRs) and then induces their dimerization, which is an essential step in activating tyrosine kinase in the receptor cytoplasmic domain, initiating a signal transduction that results in DNA synthesis and cell proliferation.(13)

Breast cancer cell growth may overexpress either estrogen receptor (ER) or EGFR. Tumors overexpressing 
EGFR are more aggressive than those expressing estrogen receptors. EGFR positivity in breast cancer is associated with estrogen receptor negativity and, hence, increased cell proliferation, insensitivity to hormonal therapy, and poor prognosis.(14)

The extent of lymph node metastasis remains the most reliable indicator for staging and progression of cancer breast.(15) However, it was suggested that in patients with lymph node metastasis, the growth of breast carcinoma was related to an accelerated EGF-dependent of cell division.(16)

This work aimed at estimation of serum levels of EGF in females with breast carcinoma and correlation between its level with the well known prognostic parameters, e.g., tumor size, grade, stage, number of lymph nodes involved, and the presence or absence of estrogen and progesterone receptors.

\section{MATERIAL AND METHODS}

Fifty-seven adult females were included after taking their consents. They were divided into two groups:

1- Patients group: It consisted of thirtyseven females with breast carcinoma with a mean age $47.8 \pm 9.94$ years. This group was further subdivided into two subgroups. a- Females without lymph nodes (LN) metastasis $(n=14)$ with a mean age $45.4 \pm 9.68$ years and bFemales with LN metastasis $(n=23)$ and their mean age was $49.3 \pm 10.03$ years.

2- Control group: Twenty normal healthy volunteer females with a mean age $45.7 \pm 8.8$ years and of comparable socioeconomic state as the patients group.

All females were chosen from the Surgery Department of the Medical Research Institute, Alexandria University. All were non-pregnant, not under contraceptive therapy, and the majority were premenopausal. 
To all females, the following were done: thorough clinical examination, plain X-ray for the chest, and ultrasonography of the abdomen and pelvis.

For the patients group, pre-operative fine needle aspiration cytology was done for the breast lumps and only those who were diagnosed as breast carcinoma were included in the study.

Following twelve hours fasting, venous blood $(\sim 6 \mathrm{ml})$ was withdrawn from each subject, allowed to clot and serum was separated. Screening laboratory tests were performed and an aliquot was immediately transferred to an Eppendorf tube for each studied subject for estimation of serum EGF. They were stored at $-20^{\circ} \mathrm{C}$ until analysis.

Screening laboratory investigations including estimation of fasting serum glucose $^{(17)}$ serum creatinine $e^{(17)}$ and uric acid $^{(18)}$ levels were done as well as determination of alanine ${ }^{(19)}$ and aspartate ${ }^{(17)}$ aminotransferase activities. Also estimation of serum EGF by ELISA ${ }^{(17,20)}$ (Biosource
International immunoassay kit, Cat number KHG 0062/ KHG 0061).

Statistical analysis was done with SPSS software package, version 11.5 (Inc Chicago IL). Results were expressed as mean $\pm S D$ for Gaussian variables and as median for non-Gaussian variables. The probability of $\mathrm{P}<0.05$ was regarded as statistically significant results.

\section{RESULTS}

Regarding the possible risk factors prevailing, 5 patients out of 37 (13.5\%) had a positive history of intake of contraceptive pills, 3 patients $(8.1 \%)$ were nulliparous and 4 patients $(10.8 \%)$ had a positive family history of malignancy, (Table 1a).

The frequency of patients with different changes in the prognostic parameters, i.e., tumor size, type, grade, and stage as well as number of $L N$ metastasis and ER \& PR status were shown in (Table 1b-g).

In (Table 2), the hemoglobin level was significantly lower in whole patients 
group and both subgroups than that in control group. While, fasting serum glucose and urea levels were significantly higher in whole patients group and in both subgroups than their corresponding levels in control group. However, no significant differences were found in the serum creatinine, ALT, or AST between all groups or subgroups, there was no significant difference in the median EGF level between the studied groups or subgroups (Table 3).

Regarding the relation of EGF level with various traditional prognostic parameters, no significant change in EGF level was detected in relation to tumor size, grade, or stage (Table 4abd). While the serum EGF level was significantly higher in patients having $\leq 3 \mathrm{LN}$ metastasis than in controls. But its level was significantly lower in patients having $>3 \mathrm{LN}$ metastasis than that in both controls or patients having $\leq 3$ LN metastasis (Table 4c).

In addition, EGF level was significantly higher in breast cancer patients with ER negative patients than that in ER positive patients (Table 4e). Also, EGF level was significantly higher in breast cancer patients having ER-ve and PR +ve than in patients having both +ve ER and PR (Table 4g). The state of PR also did not change the level of EGF (Table 4f).

(Table 5) and Figures 1-7 showed the significant correlations of EGF. 
Table 1a: characteristics of breast cance in patients group , No. (\%)

\begin{tabular}{|l|c|c|c|}
\hline Risk factors & $\begin{array}{c}\text { Hormonal } \\
\text { contraceptives }\end{array}$ & $\begin{array}{c}\text { +ve family } \\
\text { history of } \\
\text { malignancy }\end{array}$ & Nulliparity \\
\hline $\begin{array}{l}\text { Number of } \\
\text { patients }\end{array}$ & $5(13.5 \%)$ & $4(10.8 \%)$ & $3(8.1 \%)$ \\
\hline
\end{tabular}

Table 1b: Size of breast tumor in the whole patients group $(n=37)$

\begin{tabular}{|c|c|c|c|}
\hline $\begin{array}{l}\text { Tumor } \\
\text { size } \\
(\mathrm{T})\end{array}$ & $\begin{array}{c}\mathrm{T}_{1} \\
(\leq 2 \mathrm{~cm} \text { in the } \\
\text { biggest } \\
\text { diameter })\end{array}$ & $\begin{array}{c}\mathrm{T}_{2} \\
(>2 \mathrm{~cm} \text { but } \leq 5 \mathrm{~cm} \text { in } \\
\text { the biggest diameter) }\end{array}$ & $\begin{array}{c}\mathrm{T}_{3} \\
(>5 \mathrm{~cm} \text { in the } \\
\text { biggest diameter) }\end{array}$ \\
\hline $\begin{array}{l}\text { Number } \\
\text { of } \\
\text { patients }\end{array}$ & $8(21.6 \%)$ & 23 (62.2\%) & $6(16.2 \%)$ \\
\hline
\end{tabular}

Table 1c: Types of breast tumor in the whole patients group $(n=37)$.

\begin{tabular}{||c|c|c|c|c|c|}
\hline $\begin{array}{c}\text { Tumor } \\
\text { type }\end{array}$ & $\begin{array}{c}\text { Infiltrating } \\
\text { ductal } \\
\text { carcinoma } \\
\text { (IDC) }\end{array}$ & $\begin{array}{c}\text { IDC with } \\
\text { intraductal } \\
\text { component }\end{array}$ & $\begin{array}{c}\text { Medullary } \\
\text { carcinoma }\end{array}$ & $\begin{array}{c}\text { Mucoid } \\
\text { carcinoma }\end{array}$ & $\begin{array}{c}\text { Lobular } \\
\text { carcinoma }\end{array}$ \\
\hline $\begin{array}{c}\text { Number } \\
\text { of } \\
\text { patients }\end{array}$ & $26(70.3 \%)$ & $7(18.9 \%)$ & $1(2.7 \%)$ & $2(5.4 \%)$ & $1(2.7 \%)$ \\
\hline
\end{tabular}


Table 1d:Grades of breast tumor in patients having infiltrating ductal carcinoma $(n=33)$.

\begin{tabular}{||c|c|c|c|}
\hline Grade of IDCs & I & II & III \\
\hline Number of patients & $2(6.1 \%)$ & $27(81.8 \%)$ & $4(12.1 \%)$ \\
\hline
\end{tabular}

Type 1e: Lymph node metastasis in the whole patients group $(n=37)$.

\begin{tabular}{||c|c|c|c|}
\hline \multirow{2}{*}{$\begin{array}{c}\text { Lymph node } \\
\text { metastasis }\end{array}$} & No & \multicolumn{2}{|c|}{$\mathbf{N}_{\mathbf{1}}$} \\
\cline { 2 - 4 } & No LN metastasis & $\leq \mathbf{3}$ LN metastasis & $\begin{array}{c}>\mathbf{3} \text { LN } \\
\text { metastasis }\end{array}$ \\
\hline Number of patients & $14(37.8 \%)$ & $13(35.1 \%)$ & $10(27 \%)$ \\
\hline
\end{tabular}

Table 1f: Stages of breast tumor in the whole patients group $(n=37)$

\begin{tabular}{|c|c|c|c|c||}
\hline \multirow{2}{*}{ Tumor stage } & I & \multicolumn{2}{|c|}{$\begin{array}{c}\text { II } \\
\mathbf{n = 3 1}(\mathbf{8 3 . 8 \% )}\end{array}$} & III \\
\cline { 2 - 5 } & Stage I & Stage II A & Stage II B & Stage III A \\
\hline Number of patients & $3(8.1 \%)$ & $13(35.1 \%)$ & $18(48.7 \%)$ & $3(8.1 \%)$ \\
\hline
\end{tabular}

Table 1g: Estrogen receptor (ER) and progesterone receptor (PR) status in the whole patients group $(n=37)$.

\begin{tabular}{||c|cc|cc|cc|cc||}
\hline $\begin{array}{c}\text { ER and PR } \\
\text { status }\end{array}$ & ER +ve & PR+ ve & ER- ve & PR-ve & ER+ ve & PR- ve & ER- ve & PR +ve \\
\hline $\begin{array}{c}\text { Number of } \\
\text { patients }\end{array}$ & 23 & $(62.2 \%)$ & 3 & $(8.1 \%)$ & 2 & $(5.4 \%)$ & 9 & $(24.3 \%)$ \\
\hline
\end{tabular}


Table 2:Mean, S.D and P- value of blood hemoglobin level $(\mathrm{Hb})$, serum level of fasting glucose (FSG), Urea, Creatinine (Cr), aspartate (AST), Alanine (ALT) aminotransferase activities, and Epidermal growth factor (EGF) level in the studied groups.

\begin{tabular}{|c|c|c|c|c|}
\hline \multirow[b]{2}{*}{ Item } & \multicolumn{3}{|c|}{ Patients with breast cancer group } & \multirow[b]{2}{*}{$\begin{array}{c}\text { Control } \\
\text { group } \\
(n=20)\end{array}$} \\
\hline & $\begin{array}{l}\text { Whole } \\
\text { patients } \\
\text { group } \\
(\mathrm{n}=37)\end{array}$ & $\begin{array}{l}\text { Patients without } \\
\text { LN metastasis } \\
\text { subgroup } \\
(n=14)\end{array}$ & $\begin{array}{l}\text { Patients with LN } \\
\text { metastasis } \\
\text { subgroup } \\
(\mathrm{n}=23)\end{array}$ & \\
\hline $\begin{array}{l}\mathrm{Hb}(\mathrm{g} / \mathrm{dl}) \\
\text { Mean } \\
\text { S.D } \\
\text { P } \\
\mathrm{P}_{1}\end{array}$ & $\begin{array}{l}11.7^{*} \\
\pm 0.9 \\
<0.001\end{array}$ & \multicolumn{2}{|l|}{$\begin{array}{l}11.87^{*} \\
\pm 0.85 \\
<0.05\end{array}$} & $\begin{array}{c}12.47 \\
\pm 0.6\end{array}$ \\
\hline $\begin{array}{l}\text { FSG }(\mathrm{mg} / \\
\text { dl) } \\
\text { Mean } \\
\text { S.D } \\
\text { P } \\
P_{1}\end{array}$ & $\begin{array}{c}107.21^{*} \\
\pm 33.42 \\
0.001\end{array}$ & \multicolumn{2}{|l|}{$\begin{array}{c}118.07^{*} \\
\pm 36.99 \\
0.006\end{array}$} & $\begin{array}{l}86.25 \\
\pm 9.87\end{array}$ \\
\hline $\begin{array}{l}\text { Urea }(\mathrm{mg} / \\
\mathrm{dl}) \\
\text { Mean } \\
\text { S.D } \\
\text { P } \\
\mathrm{P}_{1}\end{array}$ & $\begin{array}{l}24.86^{*} \\
\pm 9.3 \\
0.003\end{array}$ & \multicolumn{2}{|l|}{$\begin{array}{l}24.71^{*} \\
\pm 9.12 \\
<0.05\end{array}$} & $\begin{array}{l}19.10 \\
\pm 4.87\end{array}$ \\
\hline $\begin{array}{l}\mathrm{Cr}(\mathrm{mg} / \mathrm{dl}) \\
\text { Mean } \\
\text { S.D } \\
\text { P } \\
\mathrm{P}_{1}\end{array}$ & $\begin{array}{c}0.91 \\
\pm 0.16 \\
\text { NS }\end{array}$ & \multicolumn{2}{|l|}{$\begin{array}{c}0.93 \\
\pm 0.13 \\
\text { NS }\end{array}$} & $\begin{array}{c}0.86 \\
\pm 0.19\end{array}$ \\
\hline $\begin{array}{l}\text { AST (U/L) } \\
\text { Mean } \\
\text { S.D } \\
\text { P } \\
P_{1}\end{array}$ & $\begin{array}{c}19.67 \\
\pm 9.93 \\
\text { NS }\end{array}$ & \multicolumn{2}{|r|}{$\begin{array}{l}20.47 \\
\pm 11.47 \\
\text { NS }\end{array}$} & $\begin{array}{l}18.2 \\
\pm 4.5\end{array}$ \\
\hline $\begin{array}{l}\operatorname{ALT}(\mathrm{U} / \mathrm{L}) \\
\text { Mean } \\
\text { S.D } \\
\text { P } \\
\mathrm{P}_{1} \\
\end{array}$ & $\begin{array}{l}21.05 \\
\pm 11.52 \\
\quad \text { NS }\end{array}$ & \multicolumn{2}{|r|}{$\begin{array}{l}21.39 \\
\pm 12.65 \\
\quad N S\end{array}$} & $\begin{array}{c}16.9 \\
\pm 7.09\end{array}$ \\
\hline $\begin{array}{l}\text { EGF (Pg/ } \\
\text { ml) } \\
\text { Mean } \\
\text { S.D } \\
\text { P } \\
P_{1} \\
\end{array}$ & $\begin{array}{c}64.64 \\
\pm 77.34 \\
\text { NS }\end{array}$ & \multicolumn{2}{|l|}{$\begin{array}{c}88.52 \\
\pm 81.66 \\
\text { NS }\end{array}$} & $\begin{array}{c}79.48 \\
\pm 79.83\end{array}$ \\
\hline
\end{tabular}

$\mathrm{P}^{*}=\quad$ Statistical significance between either patients group or subgroups and control group.

$\mathrm{P}_{1}=\quad$ Statistical significance between subgroups of patients with and without LN metastasis. 
Table 3: Serum level of epidermal growth factor (EGF) in the studied groups.

\begin{tabular}{|c|c|c|c|c|}
\hline \multirow[t]{2}{*}{ Item } & \multicolumn{3}{|c|}{ Patients with breast cancer group } & \multirow[b]{2}{*}{$\begin{array}{l}\text { Control } \\
\text { group } \\
(n=20)\end{array}$} \\
\hline & $\begin{array}{l}\text { Whole breast } \\
\text { cancer patients } \\
\text { group } \\
(n=37)\end{array}$ & $\begin{array}{l}\text { Patients without LN } \\
\text { metastasis } \\
\text { subgroup } \\
(\mathrm{n}=14)\end{array}$ & $\begin{array}{l}\text { Patients with LN } \\
\text { metastasis } \\
\text { subgroup } \\
(n=23)\end{array}$ & \\
\hline $\begin{array}{l}\text { EGF } \\
(\mathrm{Pg} / \\
\mathrm{ml}) \\
\text { Range } \\
\text { Median } \\
\mathbf{P} \\
\mathbf{P}_{1}\end{array}$ & $\begin{array}{c}5.5-303 \\
42.5 \\
\text { NS }\end{array}$ & $\begin{array}{c}5.5-303 \\
36 \\
\text { NS }\end{array}$ & $\begin{array}{c}6.5-252.5 \\
43.5 \\
\text { NS }\end{array}$ & $\begin{array}{c}11-155.5 \\
58.5\end{array}$ \\
\hline
\end{tabular}

p: Statistical significance between patients group or subgroups and control group.

$p_{1}$ : Statistical significance between subgroups of patients with and without lymph node metastasis.

Table 4a: The level of EGF in relation to breast cancer parameters

\begin{tabular}{|c|c|c|c|}
\hline & $\begin{array}{l}\text { Patients with } \\
\text { tumour size } \leq 2 \mathrm{~cm}\end{array}$ & $\begin{array}{l}\text { Patients with tumour size > } \\
2 \mathrm{~cm} \text { but } \leq 5 \mathrm{~cm}\end{array}$ & $\begin{array}{l}\text { Patients with tumour } \\
\text { size }>5 \mathrm{~cm}\end{array}$ \\
\hline & $21.6 \%$ & $62.2 \%$ & $16.2 \%$ \\
\hline \multicolumn{4}{|l|}{$\begin{array}{l}\text { EGF } \\
(\mathrm{pg} / \mathrm{ml})\end{array}$} \\
\hline Range & $5.5-209.5$ & $10.0-233.5$ & $15.0-303.0$ \\
\hline Median & 30.50 & 42.50 & 125.25 \\
\hline $\mathbf{P}$ & & NS & NS \\
\hline$p_{1}$ & & \multicolumn{2}{|c|}{ NS } \\
\hline
\end{tabular}

P: Statistical significance from patients with tumour size $\leq 2 \mathrm{~cm}$.

$P_{1}$ : Statistical significance from patients with tumour size $>2 \mathrm{~cm}$ but $\leq 5 \mathrm{~cm}$ 
Table 4b: The level of EGF in relation to tumour grade.

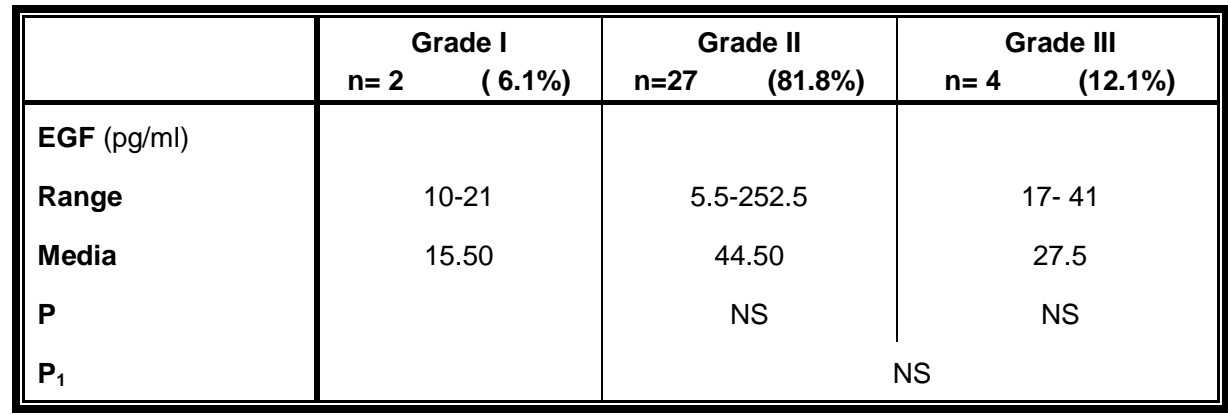

P: Statistical significance from patients with grade I.

$P_{1}$ : Statistical significance from patients with grade II.

Table 4c: The level of EGF in relation to the number of lymph node metastasis.

\begin{tabular}{|c|c|c|c|}
\hline & Negative LN & Positive LN $\leq 3$ & Positive LN > 3 \\
\hline & $n=14 \quad(37.8 \%)$ & $n=13 \quad(35.1 \%)$ & $n=10 \quad(27.1 \%)$ \\
\hline $\mathrm{EGF}(\mathrm{Pg} /$ & \multirow[b]{2}{*}{$5.5-303$} & \multirow[b]{2}{*}{$42.5-252.5$} & \multirow[b]{2}{*}{$6.5-41$} \\
\hline Range & & & \\
\hline Median & \multirow[t]{3}{*}{36} & $145.5^{\star}$ & $17.25^{\star \#}$ \\
\hline $\mathbf{P}$ & & \multirow[t]{2}{*}{0.004} & 0.019 \\
\hline $\mathbf{P}_{1}$ & & & 0.000 \\
\hline
\end{tabular}

P: Statistical significance between patients without lymph node metastasis and both subgroups with.

$P_{1}$ : Statistical significance between patients with lymph node metastasis $\leq 3$ and those with lymph node $>3$.. 
Table 4d: The level of EGF in relation to AJCC ${ }^{\star}$ stages.

\begin{tabular}{|c|c|c|c|c|}
\hline & Stage I & Stage IIA & Stage IIB & Sage IIIA \\
\hline & $\mathrm{n}=3 \quad(8.1 \%)$ & $n=13 \quad(35.1 \%)$ & $\mathrm{n}=18 \quad(48.7 \%)$ & (8.1\%) \\
\hline \multicolumn{5}{|c|}{ EGF (pg/ ml) } \\
\hline Range & 5.5- 110 & $6.5-209.5$ & $10-303$ & $15-252.5$ \\
\hline Median & 21 & 29.5 & 67.25 & 115 \\
\hline $\mathbf{P}$ & & NS & NS & NS \\
\hline P1 & & & NS & NS \\
\hline P2 & & & & NS \\
\hline
\end{tabular}

${ }^{*}$ AJCC=American Joint Commitee on Cancer.

$P$ : Statistical significance from patients with tumor stage I.

$\mathrm{P}_{1}$ : Statistical significance from patients with tumor stage IIA.

$\mathrm{P}_{2}$ : : Statistical significance from patient with tumor stage IIB

Table 4e: The level of EGF in relation to estrogen receptor (ER) positivity or negativity

\begin{tabular}{|c|c|c|}
\hline & $\begin{array}{l}\text { EGF in patients with ER+ve } \\
\qquad n=25\end{array}$ & $\begin{array}{l}\text { EGF in patients with ER-ve } \\
\mathrm{n}=12\end{array}$ \\
\hline $\begin{array}{l}\text { EGF }(\mathrm{pg} / \mathrm{ml}) \\
\text { Range } \\
\text { Median }\end{array}$ & $\begin{array}{c}5.5-173 \\
42.5\end{array}$ & $\begin{array}{c}21-303 \\
45^{\star}\end{array}$ \\
\hline $\mathbf{P}$ & & 0.049 \\
\hline
\end{tabular}

$\mathrm{P}=$ Statistical significance from EGF in patients with $E R+v e$.

Table 4f: The level of EGF in relation to progesterone receptor (PR) positivity or negativity.

\begin{tabular}{|c|c|c|}
\hline & $\begin{array}{l}\text { EGF in patients with PR+ve } \\
\mathrm{n}=32 \quad(86.5 \%)\end{array}$ & $\begin{array}{c}\text { EGF in patients with PR-ve } \\
n=5\end{array}$ \\
\hline $\begin{array}{l}\text { EGF }(\mathrm{pg} / \mathrm{ml}) \\
\text { Range } \\
\text { Median }\end{array}$ & $\begin{array}{c}5.5-303 \\
44\end{array}$ & $\begin{array}{c}29.5-115 \\
42.5\end{array}$ \\
\hline $\mathbf{P}$ & & NS \\
\hline
\end{tabular}

P: Statistical significance from EGF in patients having PR+ve. 
Table 4g: The level of EGF in relation to estrogen receptor (ER) and progesterone receptor (PR) positivity or negativity.

\begin{tabular}{|c|c|c|c|c|}
\hline & $\begin{array}{l}\text { ER+ve PR+ve } \\
n=23(62.2 \%)\end{array}$ & $\begin{array}{l}\text { ER-ve PR-ve } \\
\mathrm{n}=3 \quad(8.1 \%)\end{array}$ & $\begin{array}{l}\text { ER+ve PR-ve } \\
\mathrm{n}=2 \quad(5.4 \%)\end{array}$ & $\begin{array}{l}\text { ER-ve PR+ve } \\
n=9 \quad(24.3 \%)\end{array}$ \\
\hline \multicolumn{5}{|l|}{$\begin{array}{l}\text { EGF } \\
(\mathrm{pg} / \mathrm{ml})\end{array}$} \\
\hline Range & $5.5-173$ & $29.5-42.5$ & $42.5-115$ & $21-303$ \\
\hline Median & 41 & 40 & 78.75 & $207.5^{*}$ \\
\hline $\mathbf{P}$ & & NS & NS & 0.024 \\
\hline $\mathbf{P}_{1}$ & & & NS & NS \\
\hline $\mathbf{P}_{2}$ & & & & NS \\
\hline
\end{tabular}

P: Statistical significance from patients having both ER and PR + ve

$P_{1}$ : Statistical significance from patients having both ER and PR-ve.

$\mathrm{P}_{2}:$ : Statistical significance from patients having $E R+v e$ and $P R-v e$.

Table 5:Significant correlations between EGF and various studied items in the studied groups.

\begin{tabular}{|l|c|c|}
\hline In whole patients having breast cancer group & & $p$ \\
\hline EGF and tumor size & & \\
\hline EGF and AJCC stages & 0.341 & 0.039 \\
\hline EGF and ER status & 0.354 & 0.032 \\
\hline In patients having breast cancer without LN metastasis & -0.454 & 0.005 \\
\hline EGF and tumor size & & \\
\hline EGF and AJCC stages & 0.596 & 0.024 \\
\hline $\begin{array}{l}\text { In patients having breast cancer with lymph node } \\
\text { metastasis }\end{array}$ & 0.596 & 0.024 \\
\hline EGF and numbers of LN metastasis & & \\
\hline EGF and ER status. & -0.859 & 0.000 \\
\hline \hline
\end{tabular}




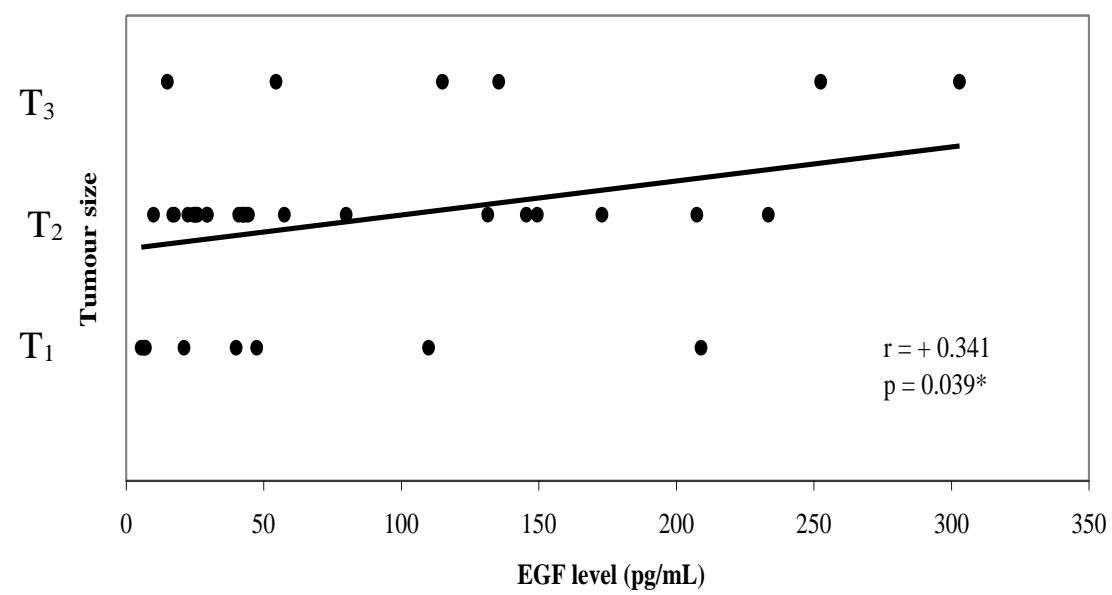

Figure (1) : Correlation between EGF level and tumour size in whole patients group.

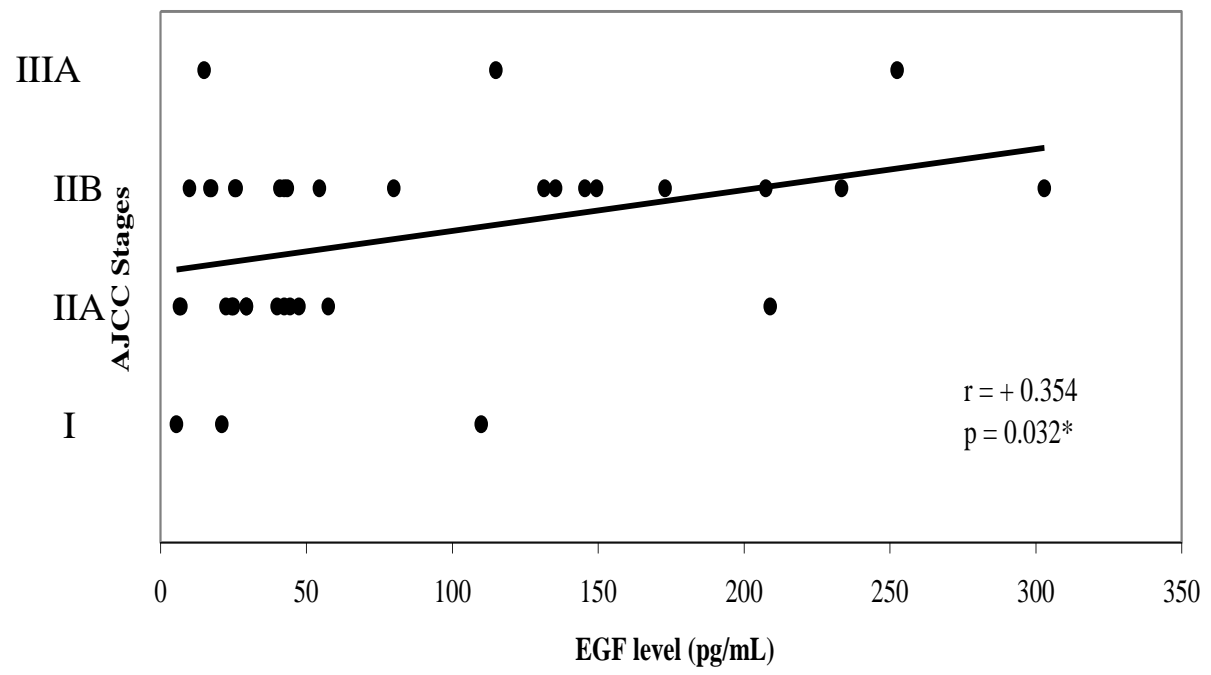

Figure (2) : Correlation between EGF level and AJCC stages in whole patients group. 


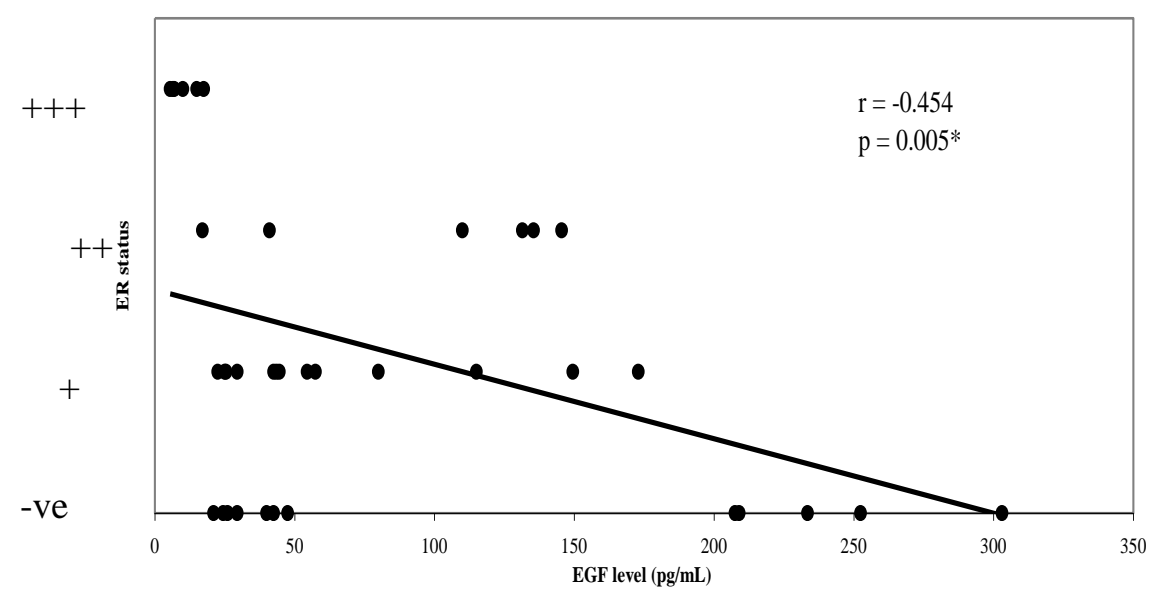

Figure (3) : Correlation between EGF level and estrogen receptor (ER) status in whole patients group.

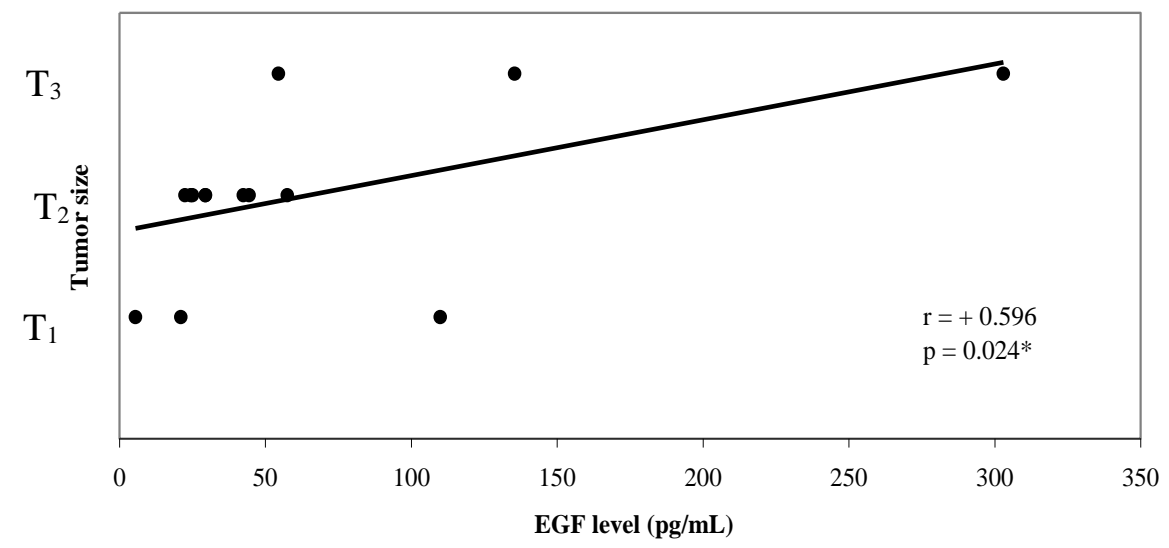

Figure (4) : Correlation between EGF level and Tumor size in patients having breast cancer without lymph node metastasis 


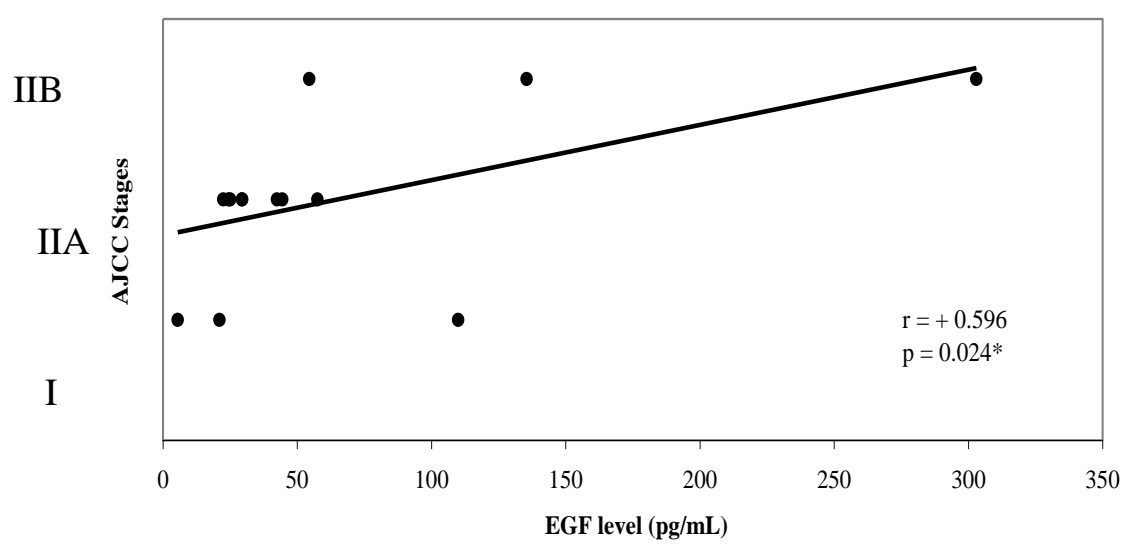

Figure (5) : Correlation between EGF level and AJCC stages in patients having breast cancer without lymph node metastasis

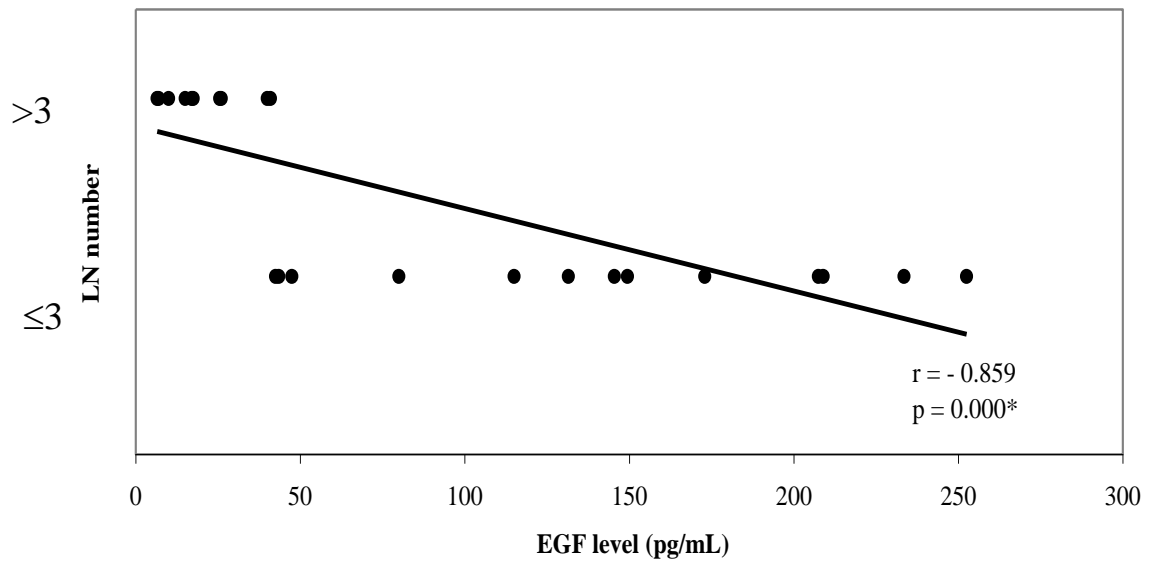

Figure (6) : Correlation between EGF level and LN number in patients having breast cancer with lymph node metastasis 


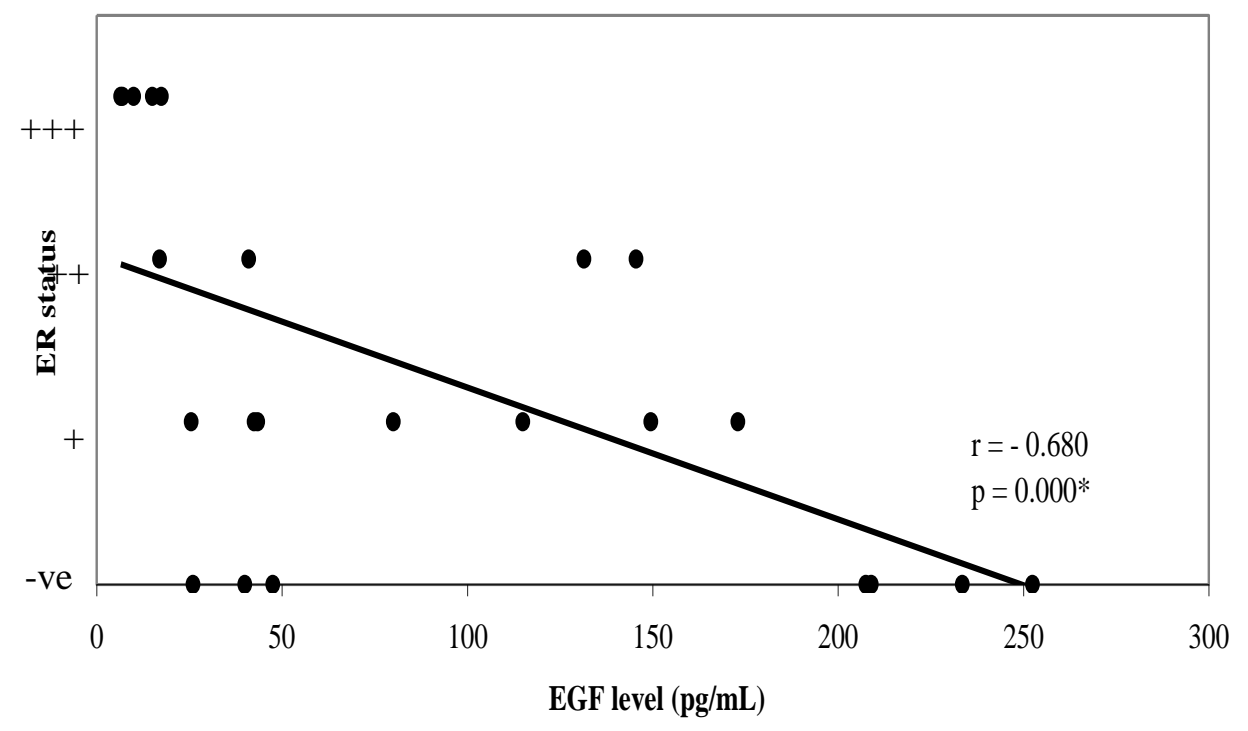

Figure (7) : Correlation between EGF level and ER status in patients having breast cancer with lymph node metastasis 


\section{DISCUSSION}

Epidermal growth factor (EGF) is a 6 $\mathrm{kDa}$, heat- and acid-stable polypeptide which stimulates proliferation of many normal and malignant cells. ${ }^{(14,21)}$

To perform its function, EGF binds with high affinity to specific low capacity receptors (EGFRs).(22) Within normal cells, the EGFR is tightly regulated.(23) Increased EGF expression has been associated with poor clinical outcome in many malignancies.(24)

Epidermal growth factor in blood of humans is found in both platlets and plasma ${ }^{(25)}$. Circulating EGF is a pool from different secretory tissues.(20) It is among the peptide growth factors active in breast glandular tumor cell proliferation and it plays a major role in breast tumor development ${ }^{(26)}$

In the present study, estimation of the serum level of EGF in thirty- seven females with breast carcinoma ranged from 5.5 to $303 \mathrm{pg} / \mathrm{ml}$ with a median of
$42.5 \mathrm{pg} / \mathrm{ml}$, showing a relative decrease than that in controls although insignificant (Table 3). This is because EGF is produced and acts locally so its concentrations in serum or urine are not necessarily relevant.(27) It was reported that tumor-associated macrophages are able to promote tumor growth directly by secreting breast tumor mitogens such as $\mathrm{EGF}^{(28)}$, also there is increase in its requirement due to its greater consumption in the tumor tissue ${ }^{-(29)}$

Navarro et al. (1997)(20) in their study showed that breast cancer patients had significantly lower plasma EGF concentrations than those in healthy women. The explanative of this low value may be that the malignant tissue requires more EGF than normal tissue for malignant transformation, cell proliferation, and invasion. ${ }^{(30,31)}$

EGF has a role in the development of fibrocystic changes in the breast, its high level is a strong prediction of breast 
cancer risk. It directs cell migration and invasion and it is also important for breast cancer progression.(10,31-33)

Lymph node metastasis in breast cancer, is the most important prognostic factor, its number has an inverse correlation with survival.(34)

On dividing the whole breast cancer females, in present study, according to the presence (23 cases) or absence of lymph node metastasis (14 cases), the serum EGF in both subgroups of patients without and with lymph node metastasis showed no significant difference from control group (Table 3). While, the serum EGF level in patients having metastasis in less than or equal to three $L N(n=13$ cases, $35.1 \%$ of whole patients) (Table 4c), showed a significant increase than its level in node negative patients. Since tumor metastases require the presence of EGF, the rise in its serum level in cancer patients with the begining of metastasis (in less than $3 \mathrm{LN}$ ) can be explained. However, with the progress of metastasis, as the EGF binds locally on cancer cells with it receptors, its serum level decreases. This was proved in the present study, as in patients having more than three $L N$ metastasis $(n=10$ cases, $27.1 \%$ of whole patients), the serum EGF showed a significant decrease than its level in node negative patients and those with metastasis in less than or equal three LN (Table 4c).

In addition, in the patients having breast cancer with LN metastasis, EGF showed significant negative correlation with the number of $L N$ metastasis ( $r=-$ 0.859, $P=0.000)$, (Table 5) and (Figure 6). This goes in agreement with the work of Bolufer et al. (1993). (35)

Tumor size is an important prognostic factor in breast cancer patients having an inverse correlation with survival.(34) In the present study, although there was a trend for the median of EGF concentration to increase with increase 
in tumor size, but this trend did not reach the level of statistical significance (Table 4a). This finding is in accordance with other studies. $(35,36)$

In addition, both in the whole patient group and in the subgroup of patients without LN metastasis, serum EGF showed a significant positive correction with tumor size $(r=0.341, P=0.039)$ and $(r=0.596, P=0.024)$ (Table 5$)$ and (Figures 1 \& 4). These positive correlations between serum EGF and tumor size proved the stimulatory effect of EGF on cell proliferation and tumor growth. ${ }^{(31)}$

There are certain morphological types of breast cancer which have a distinct favourable clinical course. In the present study, infiltrating ductal carcinoma was the predominant type (70.3\%) (Table 1c). There was no statistically significant relationship between EGF levels and tumor type. This finding is in the accordance with another previous study.(36)

The grading of breast tumor is another important prognostic factor including nuclear characteristics and degree of differentiation. (34) In the present study, most patients (81.8\%) had tumors with grade II. (Table 1d). Since the number of patients with grade I and grade III breast carcinoma is too small, there was no significant difference in the serum EGF levels in relation to tumor grading (Table 4b). This finding was in accordance with other studies $\cdot(33,35,36)$

The American Joint Committee on Cancer (AJCC) published in 2006, a breast cancer staging system based on the TNM classification. ${ }^{(37,38)}$ In the present study, there was a tendency of increased serum EGF with the progress of the stage of breast carcinoma, yet this increase was not statistically significant because of the wide range in the EGF level and the small sample size in 
patients with stage I and III A (Table 4d). levels showed significant negative This tendency to increase in EGF level correlation with ER positivity $(r=-0.454$, with the progress of staging is due to the $\mathrm{P}=0.005)$ (Table 5) and (Figure 3). stimulatory effect on EGF in tumor Similar results were also reported. $(14,35,42)$ growth, invasion, and metastasis.(30) It was reported the fact that the

This was also proved in both the whole patients group and in the subgroup of patients without LN metastasis, since the EGF showed significant positive correlation with AJCC stages $(r=0.354, P=0.032)$ and $(r=0.596$, $\mathrm{P}=0.024)$ (Table 5) and (Figures 2 \& 5).

Estrogen receptor is dominant regulator and a key therapeutic target in cancer etiology and progression.(39) Higher estrogen receptors (ER) concentrations were positive and lower concentrations were negative prognostic factors for disease free survival. ${ }^{(40,41)}$ In the present study, serum EGF level in patients having ER-ve showed a significant increase than that in patients having ER+ve (Table 4e). In addition, in the whole patients group, serum EGF magnitude of EGF binding on tumors was independent of either estrogen or progesterone receptor. The highest quantities of EGF binding were expressed on tumors lacking steroid receptors. ${ }^{(43)}$ Epidermal GF receptor positive tumors are hormone unresponsive and more aggressive than EGF receptor negative tumors ${ }^{(13,14,44)}$

It was proposed that EGF is the driving force for the autonomous growth of ER negative breast cancer cell via the EGF - EGFER - initiated signal transduction pathway.(45)

In the present study, serum EGF level showed no significant difference in patients with progesterone receptors positive (PR+ve) and (PR-ve) tumors (Table 4f). The findings are in 
accordance with other studies. ${ }^{(35,36)}$

However, another study suggests that progesterone and EGF may play opposing roles in metastasis.(46)

On combining the state of ER and PR in the present study, the serum level of EGF showed a significantly higher level in patients with ER-ve but $P R+v e$ tumors than that in those with both ER and PR+ve tumors (Table 4g). However, those with both ER and PR-ve tumors or those with ER+ve and PR-ve tumors did not show such increase because of their small sample size. This finding denotes that the presence of ER -ve tumors increases the over expression of EGF that occurs in malignancy. ${ }^{(20)}$ In addition, since EGF stimulates the synthesis of its own receptor, it was suggested that EGF is a major growth-stimulating factor for ER-ve cells through the effect of EGFR. ${ }^{(45)}$

In conclusion, determination of serum EGF level in combination with the known prognostic parameters is useful in determining the tumor prognosis and more beneficial results could be attained if its determination is combined with the determination of EGFR on tumor tissue.

\section{RECOMMENDATION}

Further studies are necessary in order to assess the possible clinical value of EGFR.

\section{REFERENCES}

1. Bhalla V, Joshi K, Vohra H, Singh G, Ganguly N. Effect of growth factors on proliferation of normal, borderline and malignant breast epithelial cells. Exp Mol Pathol.2000; 68: 124-32.

2. Stull $M$, Rowzee A, Loladze A, Wood T. Growth factor regulation of cell cycle progression in mammary epithelial cell. J Mammary gland Biol Neoplasia. 2004; 9: 15-26.

3. Sutherland RL, Lee CS, Feldman RS, Musgrove EA. Regulation of breast cancer cell cycle progression by growth factors, steroids and steroid antagonists. J Steriod Biochem Mol Biol.1992; 41: 315-21.

4. Haraguchi S, Good R, Engelman R, Greene S, Day N. Prolactin, epidermal growth factor or transforming growth factor-alpha activates a mammary cell-specific enhancer in mouse mammary tumor virus-long terminal repeat. Mol Cell Endocrinol. 1997; 129: 145-55.

5. Strange $\mathrm{K}$, Wilkinson D, Edin G, Emerman J. Mitogenic properties of insulin-like growth factor-I and -II, insulin-like growth factor binding 
protein-3 and epidermal growth factor on human breast stromal cells in primary culture. Breast Cancer Res Treat. 2004; 84: 77-84.

6. Ethier S, Summerfelt, Cundiff K, Asch $B$. The influence of growth factors on the proliferative potential of normal and primary breast cancer-derived human breast epithelial cells. Breast Cancer Res Treat. 1991; 17: 221-30.

7. He-Shul I, Ji-Jie C, Ming L, BingRen $\mathrm{H}$, Cun-Heng $\mathrm{H}$, Ru-Chang $\mathrm{B}$. Crystal structure of human epidermal growth factor and its dimerization. J Biol Chemistry. 2001; 276: 34913-7.

8. Burgess A. Epidermal growth factor and transforming growth factor- $\alpha$ British Medical Bulletin. 1989; 45: 401-24.

9. Litwack G, Schmidt TJ. Biochemistry of hormones I: Polypeptide hormones. In: Devlin T. ed Textbook of Biochemistry with clinical correlation. 5th Ed. New York: Wiley Liss (Pub); 2002. pp. 906-950.

10. Boccardo F, Lunardi GL, Petti AR, Rubagotti A. Enterolactone in breast cyst fluid: correlation with EGF and breast cancer risk. Breast Cancer Res Treat. 2003; 79: 17-23.

11. Warner BW, Warner BB. Role of epidermal growth factor in the pathogenesis of neonatal necrotizing enterocolitis. Semin Pediatr Surg. 2005; 14: 175-80.

12. Aybay C, Karakus R, Yucel A. Characterization of human epidermal growth factor in human serum and urine under native conditions. Cytokine. 2006; 35: 3643.

13. Lo HW, Hsu SC, Hung MC. EGFR signaling pathway in breast cancers: from traditional signal transduction to direct nuclear translocalization. Breast Cancer Res Treat. 2006; 95: 211-8.

14. Lai LC. Role of steroid hormones and growth factors in breast cancer. Clin Chem Lab Med. 2002; 40: 96974.

15. Le Bedis C, Chen K, Fallavollita I, Boutros T, Brodt P. Peripheral lymph node stromal cells can promote growth and tumorigenicity of breast carcinoma cells through the release of IGF-1 and EGF. Int $\mathrm{J}$ Cancer. 2002; 100: 2-8.

16. Spitzer K, Koepke K, Kunde D, Grosse R. EGF binding is quantitatively related to growth in node-positive breast cancer. Breast Cancer Res Treat. 1988; 12: 45-9.

17. Burtis CA, Ashwood ER, Bruns DE. Tietz Textbook of Clinical Chemistry and Molecular Diagnostics, 4th Ed. St Louis: Elsevier Saunders Company; 2006, pp. 870, 798, 604607, 235-236.

18. Burtis CA, Ashwood ER. Tietz textbook of clinical chemistry, 3rd Ed. Philadelphia: W.B Saunders Company; 1999, pp. 1249-1250.

19. Berg Meyer MU, Horder M. IFCC method for alanine aminotransferase. Clin Chem Acta. 1980; 105: 147-72.

20. Navarro M, Mesia R, Diez-Gibert O, Ojeda B, Alonso M. Epidemal growth factor in plasma and saliva of patients with active breast cancer and breast cancer patients in followup compared with healthy women. Breast Cancer Res Treat. 1997; 42: 83-6.

21. Artagaveytia N, Le Penven S, Falette N, Lucero R, Garofalo EG, Saez S. Epidermal growth factor and transforming growth factor alpha mRNA expression in human breast cancer biopsies; analysis in 
relation to estradiol, progesterone and EGF receptor content. J Steroid Biochem Mol Biol. 1997; 60: 221-8.

22. Vander Heiden MG, Plas DR, Pathmell JC, Fox CJ, Harris $\mathrm{MH}$, Thompson CB. Growth factors can influence cell growth and survival through effects on glucose metabolism. Mol Cell Biol. 2001; 21 : 5899-912.

23. Cohenuram M, Saif MW. Epidermal growth factor receptor inhibition strategies in pancreatic cancer: past, present and the future. JOPJ Pancreas. 2007; 8: 4-15.

24. Quintela I, Corte MD, Allende MT, Vazquez J, Rodriguez JC, Bongera $M$, et al. Expression and prognostic value of EGFR in invasive breast cancer. Oncol Rep. 2005; 14: 165563.

25. Kanazawa S, Yamaguchi K, Kinoshita $Y$, Muramatsu M, Komiyama Y, Nomura S. Gefitinib affects functions of platelets and blood vessels via changes in prostanoids balance. Clin Appl Thromb Hemost. 2005; 11: 429-34.

26. Ribeiro ML, Aisenberg J, Billi $S$, Farina MG, Meiss R, Mc Cann S, et al. Epidermal growth factor prevents prepartum luteolysis in the rat. Proc Natl Acad Sci. 2005; 102: 8048-53.

27. Fitzpatrick SL, Brightwell J, Wittliff JL, Barrows GH, Schulz GS. Epidermal growth factor binding by breast tumor biopsies and relationship to estrogen receptor and progestin receptor levels. Cancer Res. 1984; 44: 3448-53.

28. Leck RD, Harris AL. Tumor associated macrophages in breast cancer. J Mammary Gland Biol Neoplasia. 2002; 7: 177-89.

29. Baccardo F, Lunardi GL, Petti AR, Rubagotti A. Enterolactone in breast cyst fluid: correlation with EGF and breast cancer risk. Breast Cancer Res Treat. 2003; 79: 17-23.

30. Binder C, Hagemann T, Husen B, Schulz M, Einspanier A. Relaxin enhances in-vitro invasiveness of breast cancer cell lines by upregulation of matrix metalloproteases. Mol Hum Reprod. 2002; 8: 789-96.

31. Daniel AR, Qiu M, Faivre EJ, Ostrander JH, Skildum A, Lange CA. Linkage of progestin and epidermal growth factor signaling: Phosphorylation of progesterone receptors mediates transcriptional hypersensitivity and increased ligand-independent breast cancer cell growth. Steroids. 2007, 72: 188201.

32. Kast C, Wang M, Whiteway M. The ERK/MAPK pathway regulates the activity of the human tissue factor pathway inhibitor-2 promoter. J Biol Chem. 2003; 278: 6787-94.

33. Zeineldin R, Hudson LG. Epithelial cell migration in response to epidermal growth factor. Methods Mol Biol. 2006; 327: 147-58.

34. Stoica A, Saceda M, Doraiswamy VL, Coleman C, Martin MB. Regulation of estrogen receptors $\alpha$ gene expression by epidermal growth factor. Journal of Endocrinology. 2000; 165: 371-8.

35. Bolufer $\mathrm{P}$, Lluch A, Molina R, Alberola V, Vazquez C, Padilla J, et al. Epidermal growth factor in human breast cancer, endometrial carcinoma and lung cancer. Its relationship to epidermal growth factor receptor, estradiol receptor and tumor TNM. Clin Chim Acta. 1993; 215: 51-61.

36. Ferrero JM, Ramaioli A, Largillier R, Formento JL, Francoual M, Ettore F, et al . Epidermal growth factor receptor expression in 780 breast 
cancer patients: a reappraisal of the prognostic value based on an eightyear median follow-up. Ann Oncol. 2001; 12: 841-6.

37. Bandyopadhyay GK, Imgawa W, Wallace DR, Nandi S. Proliferative effect of insulin and epidermal growth factor on mouse mammary epithelial cells in primary culture. The Journal of Biological Chemistry. 1988; 263: 7567-73.

38. Singletary SE, Conolly JL. Breast cancer staging: Working with the sixth edition of the AJCC cancer staging manual. CA Cancer J Clin. 2006; 56: 37-47.

39. Frassoldati A, Maur M, Guarneri V, Nicolini M, Conte PF. Predictive value of biologic parameters for primary chemotherapy in operable breast cancer. Clin Breast Cancer. 2005; 6: 315-24.

40. Skasko E, Pszko Z, Mazur S. A new look at the prognostic value of estrogen, progesterone and epidermal growth factor receptors in breast cancer tissue. Neoplasma. 2005; 52: 10-7.

41. Calaf GM, Roy D, Hei TK. Growth factor biomarkers associated with estrogen- and radiation-induced breast cancer progression. Int $\mathrm{J}$ Oncol. 2006; 28: 87-93.

42. Gann $\mathrm{P}$, Chatterton $\mathrm{R}$, Vogelsong $\mathrm{K}$, Dupuis J, Ellman A. Mitogenic growth factors in breast fluid obtained from healthy women. Evaluation of biological and extraneous sources of variability. Cancer Epidemiology, Biomarkers \& Prevention. 1997; 6: 421-8.

43. Biswas DK, Dai SC, Cruz A, Weiser $B$, Graner E, Pardee AB. The nuclear factor kappa B (NF-Kappa B): a potential therapeutic target for estrogen negative breast cancers. Proc Natl Acad Sci. 2001; 98: 10386-9.

44. Abd El-Rehim DH, Pinder SE, Paish CE, Bell JA, Rampaul RS, Blamey RW, et al. Expression and coexpression of the members of the epidermal growth factor receptor (EGFR) family in invasive breast carcinoma. $\mathrm{Br} \mathrm{J}$ Cancer. 2004; 91 : 1532-42.

45. Garcia R, Franklin RA, Mc Cubrey JA. Cell death of MCF-7 human breast cancer cells induced by EGFR activation in the absence of other growth factors. Cell Cycle. 2006; 5: 1840-6.

46. Pang $H$, Rowan BG, Al-Dhaheri $M$, Faber LE. Epidermal growth factor suppresses induction by progestin of the adhesion protein desmoplakin in T47D breast cancer cells. Breast Cancer Res. 2004; 6: 239-45. 
